\title{
Occurrence of Cyanobacteria and Microcystin variants in Musina Raw Water Supply and Limpopo River Sediment, South Africa
}

\author{
Gumbo JR, Netshambidi LK and Mavhunga P
}

\begin{abstract}
The nutrient enrichment of freshwater dams, rivers and lakes leads to propagation of cyanobacteria which are a major concern due to microcystins in South Africa and worldwide. The presence of microcystins may be a source of natural organic matter (NOM) in raw water supply which stimulates the growth of cyanobacteria. Here we report on the occurrence of cyanobacteria and diatoms in Musina raw water supply and Limpopo river sediments. The study showed that source of cyanobacteria and diatoms were the river sediments. The FlowCAM and scanning electron microscope (SEM) identified three cyanobacteria genera: Oscillatoria, Microcystis and Planktothrix. The physico-chemical analysis of the river sediment and water samples showed low levels of clay particles, high levels of nitrates, inorganic phosphorus and total phosphorus. The UV-Vis spectrophotometric method and total organic carbon (TOC) analyzer confirmed presence of specific ultra-violet absorbance (SUVA) and dissolved organic carbon (DOC) levels in the water samples. The high DOC levels and nutrients in the raw water and sediments stimulate the growth of cyanobacteria and the production of microcystins. High pressure liquid chromatography with a photodiode array detector (HPLC-PDA) then confirmed the presence of microcystin LR and YR in the water samples.
\end{abstract}

Keywords - river sediments; dissolved organic carbon; Microcystis; raw water supply

\section{INTRODUCTION}

The nutrient enrichment of freshwater dams, rivers and lakes leads to propagation of cyanobacteria which are a major concern because of production hazardous cyanotoxins in South Africa and worldwide [1-4]. Natural organic matter (NOM) is a complex organic material that is found in natural surface water sources as a result of the biodegradation of plants by microbes [5].Thus the water resources that are used for domestic and industrial purposes commonly contain natural organic matter (NOM) and is called dissolved organic carbon (DOC) [6]. The NOM has the potential to encourage bacterial formation which may on the long term affect human health [7].

Manuscript received October 20, 2020

Prof JR Gumbo is with Department of Hydrology and Water Resources, University of Venda,

Ms LK Netshambidi was Honours student with Department of Hydrology and Water Resources, University of Venda,;

Mr P Mavhunga was Honours student with Department of Ecology and Resource Management, University of Venda,
The occurrence of cyanobacteria, mostly Microcystis species, in sediments even in deeper layers has been observed microscopically [8]. The presence of cyanobacteria both in water column and sediments may cause an adsorption of their toxins in sediment layers, because 65 to $85 \%$ of the benthic stock may be subjected to decay [9]. As reported by Morris et al. [10], clay minerals appear to be very effective in microcystin adsorption from water solution. The microcystins released into water during cyanobacteria bloom decay are comparatively persistent in aquatic environment [11]. They can be degraded by exposure to ultraviolet radiation or microbial activity [12-13]. During unfavourable environmental conditions, a few planktonic cyanobacteria species persist as resting/dormant stages that subsist in the sediments [13]. Characteristics such as texture, surface area, pore size distribution, and $\mathrm{pH}$ are the important factors that affect the extent of adsorption capacity of cyanotoxins onto the sediment [14].

The source of drinking water for Musina town is Limpopo River. The raw water is pumped from 19 boreholes that have been drilled in the Limpopo River and then subjected to chlorination before distributed to the town. The main objective of the study is to determine occurrence of cyanobacteria and microcystins in the Musina raw water supplies and the Limpopo river sediments. The specific objectives were: to determine the physical-chemical parameters of the Musina raw water and river sediments; to determine the dissolved organic carbon in Musina raw water supply; to identify cyanobacteria species that were present in Musina raw water supply and river sediments and to determine the levels of microcystins that were present in the Musina raw water.

\section{MATERIALS AND MethodS}

\section{A. The Study Area}

The water and sediment samples were collected from abstraction point (Fig 1). 


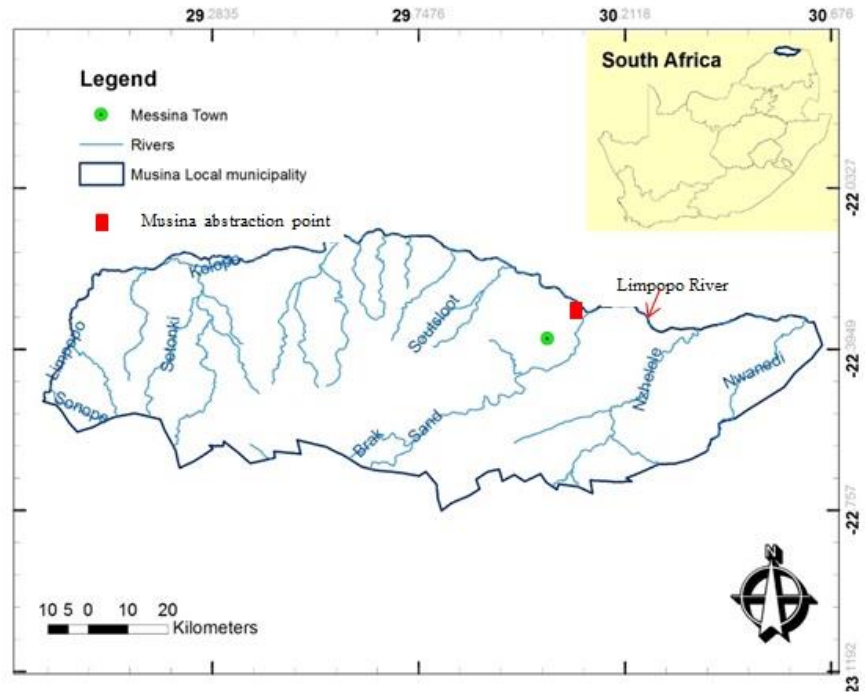

Fig 1. The location of raw water supply point and Musina town.

\section{B. Sample collection and preparation}

The water and sediment samples for this study were collected from the study area (Table 1). To collect sediments from such deeper depth a hand auger was used. The water samples were collected in two plastic $250 \mathrm{ml}$ plastic containers of which one plastic container was sterilized prior to sampling. To the non-sterile plastic container, physico-chemical analyses were later performed. To the sterile plastic container, this was later incubated at room temperature $\left(30\right.$ to $38{ }^{\circ} \mathrm{C}$ ) for period of 30 days under continuous light conditions. The water samples were collected monthly from November 2012 to February 2013. All samples were stored in a refrigerator in the dark before use.

TABLE I: THE DESCRIPTION OF THE WATER AND SEDIMENT SAMPLE POINTS

\begin{tabular}{ll}
\hline \hline Sample point & Sample description \\
\hline Water tap 1 & $\begin{array}{l}\text { Tap outlet directly linked to one borehole located in } \\
\text { the Limpopo riverbed } \\
\text { Tap outlet from central reservoir, holds raw water } \\
\text { from other all 19 boreholes }\end{array}$ \\
Water tap 2 & $\begin{array}{l}\text { Collected at the surface of riverbed }(0 \mathrm{~m}) \\
\text { Sediment } 1\end{array}$ \\
Sediment 2 & Collected at a depth of $1.00 \mathrm{~m}$ from the riverbed \\
Sediment 3 & Collected at a depth of $1.68 \mathrm{~m}$ from the riverbed \\
\hline \hline
\end{tabular}

C. The physical-chemical and nutrient analysis of water samples

\section{1) On-site physical analysis}

The physical parameters, $\mathrm{pH}, \mathrm{EC}$, TDS were performed in triplicate for the water samples. The $\mathrm{pH}, \mathrm{EC}$ and TDS were analyzed using a combination of $\mathrm{pH}$ and electrical conductivity probe from HANNA Instruments. The calibration of the $\mathrm{pH}$ and electrical conductivity was carried out with standards supplied by the manufacturer.

\section{2) Nutrient analysis}

The nutrients, phosphate and nitrate, were analyzed on the Ion Chromatography Metrohm 850 professional IC (Metrohm, Switzerland) was used and the procedure of Pereira et al. [15] was followed. The measurements were conducted in triplicates and the standard deviation and the mean of the concentration were calculated.

\section{3) The analysis of Dissolved Organic Carbon}

The same water samples were pre-filtered through a $0.45 \mu \mathrm{m}$ filter (GVS Filter, USA) and then were also sent to University of Johannesburg who carried out the dissolved organic carbon (DOC) analysis. The DOC was measured with a total organic carbon (TOC) analyzer (Fusion instrument) according to procedure of Nkambule et al. [16]. The TOC analyzer was calibrated, prior to use, with a series of Potassium hydrogen phthalate (KHP) standards of $1 \mathrm{mg} / \mathrm{l}, 5 \mathrm{mg} / \mathrm{l}, 10 \mathrm{mg} / \mathrm{l}, 20 \mathrm{mg} / \mathrm{l}$ and $30 \mathrm{mg} / \mathrm{l}$ Carbon that were prepared in deionized water.

4) Ultraviolet visible (UV-Vis) spectrophotometric analysis

The waters samples were pre-filtered through a $0.45 \mu \mathrm{m}$ filter (GVS Filter, USA) and were analyzed at University of Limpopo who carried out the UV-Vis spectrophotometric analysis in the following wavelengths: $214 \mathrm{~nm} ; 254 \mathrm{~nm} ; 272 \mathrm{~nm}$ and $300 \mathrm{~nm}$. The absorbances at $254 \mathrm{~nm}$ were used to calculate the Specific Ultra-Violet Absorbance (SUVA) as this equation (1).

$$
\operatorname{SUVA}\left(\frac{L}{m g \cdot M}\right)=\frac{U V_{254}\left(\mathrm{Cm}^{-1}\right)}{\operatorname{DOC}\left(\frac{m g}{L}\right)} X 100 \quad \text { equation } 1
$$

\section{5) The analysis of microcystins in the raw water supply}

The same water samples were pre-filtered through a $0.45 \mu \mathrm{m}$ filter (GVS Filter, USA) and then were also sent to University of Johannesburg who carried out the analysis of microcystins. $100 \mathrm{~mL}$ of water sample was filtered through a $0.45 \mu \mathrm{m}$ membrane filter and the filtrate divided into three $10 \mathrm{ml}$ portions. Oasis ${ }^{\circledR}$ HLB 3 cc/60 mg was used. The Extracts were analyzed by the Surveyor Plus ${ }^{\mathrm{TM}}$ modular LC system and the ChromQuest $^{\mathrm{TM}}$ data system, products of Thermo Fisher Scientific San Jose, on a $150 \times 4.6 \mathrm{~m}, 5 \mu \mathrm{m}$ column (waters) at $30{ }^{\circ} \mathrm{C}$ with a mobile phase composition of $60 \%$ water $+0.1 \%$ formic acid and $40 \%$ acetonitrile $+0.1 \%$ formic acid at a flow rate of $1.0 \mathrm{mLmin}^{-1}$. The Surveyor Plus modular LC system consists of the Surveyor LC Pump Plus, the Surveyor Auto sampler Plus, and the Surveyor PDA plus Detector. Chromatograms at $238 \mathrm{~nm}$ were recorded with the Surveyor PDA plus Detector, and microcystin (MCYST) were identified by retention time and characteristic UV absorption spectra (200-300 nm). Quantification was based on external calibrations of MCYST-RR, -LR, LY and -YR, respectively. The injections were in triplicate.

\section{The physical-chemical and nutrient analysis of river sediments}

\section{1) Total phosphorus (TP) analysis}

Total phosphorus (TP) was determined by use of the perchloric acid digestion method as described by APHA [17]: 2 $\mathrm{g}$ of air dried sediment was acidified to methyl orange with concentrated $\mathrm{HNO}_{3}$, another $5 \mathrm{ml}$ concentrated $\mathrm{HNO}_{3}$ was added and evaporated on a hot plate to $15 \mathrm{ml} .10 \mathrm{ml}$ each of concentrated $\mathrm{HNO}_{3}$ and $\mathrm{HClO}_{4}$ was added and evaporated gently until the dense white fumes of $\mathrm{HClO}_{4}$ appear. The 
solution was then neutralized with $6 \mathrm{~N} \mathrm{NaOH}$ and made up to $100 \mathrm{ml}$ with distilled water.

\section{2) Total Inorganic phosphorus (TIP) analysis}

Total inorganic phosphorus (TIP) was determined according to [18]: $1 \mathrm{~g}$ of air dried sediment was ignited in a muffle furnace at a temperature of $550{ }^{\circ} \mathrm{C}$ for 1 hour, and dissolved in $25 \mathrm{ml}$ of $1 \mathrm{M} \mathrm{HCl}$ solution and determined as total inorganic phosphorus according to Strickland and Parsons [19].

\section{3) Total nitrogen analysis}

Total Nitrogen was determined according to Hilal and Alhaija [20] as ammonia: $1 \mathrm{~g}$ of each air dried sediment sample was treated with $2 \mathrm{ml}$ of sulphuric acid. The sample was heated on a hotplate for 2 hours. Aliquots of $50 \mathrm{ml}$ of deionized water were added to each sample. The sample was filtrated through No. 41 Whatman filter paper. The filtrate of each sample was made up to $250 \mathrm{ml}$ with deionized water and $55 \mathrm{ml}$ of $1 \mathrm{M}$ sodium hydroxide solution.

\section{4) Particle size analysis}

A determination of particle size distribution was done with sieving method; $240 \mathrm{~g}$ of air-dried sediments was transferred directly into a sieve column. The sieve separation column was shacked for 1 hour. Mass retained on each sieve was recorded and presented as percentage.

\section{E. The culture of cyanobacteria of river sediments}

In the laboratory the BG11 medium was prepared as per procedure of Krüger and Eloff [21]. Under sterile conditions the $1.0 \mathrm{~g}$ river sediments were transferred in to $250 \mathrm{ml}$ Erlenmeyer flasks containing $200 \mathrm{ml}$ of BG11 medium and were incubated for 30 days under continuous light (1100 lux) of white florescent lamps at a room temperature.

1) The presence of cyanobacteria species in raw water and river sediments

The sterile plastic containers were incubated at room temperature (30 to $38{ }^{\circ} \mathrm{C}$ ) for period of 30 days under continuous light conditions $(1076 \pm 204$ lux $)$. Later after 30 days, the water samples were subjected to flow cytometric analysis. A bench top FlowCAM (Model VS IV) was used to determine the composition of algae and cyanobacteria species that were growing in the samples. The FlowCAM was equipped with a blue $(488 \mathrm{~nm})$ laser for florescent and particle detection. For the analysis of algal composition in natural field samples a flow cell (FC300) was used with $4 \mathrm{X}$ objective and a cell size range of 20 to $300 \mu \mathrm{m}$. The water samples were transferred to the funnel with a pipette. The fluorescent particle/cell was digitally acquired and archived by the FlowCAM for latter processing. This instrument will capture images which were then used to identify the cyanobacteria image by comparison to literature. A confirmatory analysis based on scanning electron microscope will also be used as per procedure of Gumbo and Cloete [22]. The captured images were identified by comparison with published images from literature.

\section{F. Data analysis}

The Microsoft excel software was used to calculate the mean, standard deviation and carry out statistical analysis with single factor ANOVA to assess any significance differences between microcystins concentrations across months, water tap and microcystin congeners at $\mathrm{P}<0.05$ significance level.

\section{RESULTS AND DISCUSSIONS}

\section{A. The effects of physico-chemical parameters on cyanobacteria communities in the water samples}

The water samples were then incubated at room temperature under continuous lighting to stimulate the growth of cyanobacteria. After incubation for 30 days, some of the plastic containers had a green colour (water tap 2) and others did not have a green colour (water tap 1). This may imply that the presence of nutrients, dissolved organic carbon and light may influence the growth of cyanobacteria in the raw water. The physical chemical analysis of raw water showed variation between the months from November to January (Table 2). The $\mathrm{pH}$ was slightly alkaline, with a range of 7.27 to 7.54 (water tap 1) and 7.12 to 7.73 (water tap 2). The alkaline $\mathrm{pH}$ is one of the factors that may promote the growth of cyanobacteria as shown by sample from water tap 2 [23].

TABLE II: THE PHYSICO-CHEMICAL CHARACTERISTICS OF WATER QUALITY DURING THE STUDY PERIOD

\begin{tabular}{|c|c|c|c|c|c|c|c|}
\hline \multirow{2}{*}{\multicolumn{2}{|c|}{$\begin{array}{l}\text { Month } \\
\text { Sample point }\end{array}$}} & \multicolumn{2}{|c|}{ Nov 2012} & \multicolumn{2}{|c|}{ Dec 2012} & \multicolumn{2}{|c|}{ Jan 2013} \\
\hline & & WT1 & WT2 & WT1 & WT2 & WT1 & WT2 \\
\hline \multicolumn{2}{|c|}{$\begin{array}{l}\text { Limpopo River } \\
\text { flow }\end{array}$} & Zero* & Zero* & $\begin{array}{l}\text { Mode } \\
\text { rate** }\end{array}$ & $\begin{array}{l}\text { Mode } \\
\text { rate** }\end{array}$ & $\begin{array}{l}\text { High } \\
* * *\end{array}$ & $\begin{array}{l}\text { High } \\
* * *\end{array}$ \\
\hline \multicolumn{2}{|l|}{$\mathrm{pH}$} & 7.54 & 7.73 & 7.57 & 7.34 & 7.27 & 7.12 \\
\hline \multicolumn{2}{|c|}{ Salinity $\mathrm{mg} / \mathrm{l}$} & 0.5 & 0.4 & 0.6 & 0.5 & 0.5 & 0.4 \\
\hline \multicolumn{2}{|c|}{$\mathrm{EC} \mu \mathrm{S} / \mathrm{cm}$} & 96.2 & 75.5 & 96.7 & 73.5 & 96.7 & 71.5 \\
\hline \multicolumn{2}{|c|}{ Nitrates mg/l } & 0.5 & 0.6 & 0.8 & 0.7 & 0.7 & 0.6 \\
\hline \multicolumn{2}{|c|}{ Phosphates mg/l } & -- & -- & -- & -- & -- & -- \\
\hline \multirow{4}{*}{ 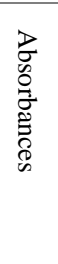 } & $\begin{array}{l}214 \\
\mathrm{~nm}\end{array}$ & 0.495 & 0.196 & 2.287 & 0.248 & 2.295 & 1.798 \\
\hline & $\begin{array}{l}254 \\
\mathrm{~nm}\end{array}$ & 0.134 & 0.106 & 0.155 & 0.151 & 0.160 & 0.104 \\
\hline & $\begin{array}{l}272 \\
\mathrm{~nm}\end{array}$ & 0.114 & 0.093 & 0.132 & 0.136 & 0.136 & 0.093 \\
\hline & $\begin{array}{l}300 \\
\mathrm{~nm}\end{array}$ & 0.083 & 0.071 & 0.099 & 0.111 & 0.101 & 0.074 \\
\hline \multicolumn{2}{|c|}{ DOC (ppm) } & 2.31 & 2.84 & 2.46 & 7.27 & 2.43 & 2.43 \\
\hline \multicolumn{2}{|c|}{ SUVA $1 / \mathrm{mg} . \mathrm{M}$} & 5.81 & 3.73 & 6.30 & 2.08 & 5.85 & 4.28 \\
\hline \multicolumn{2}{|c|}{ Microcystin RR } & -- & -- & -- & -- & -- & $\$$ \\
\hline \multicolumn{2}{|c|}{ Microcystin LR } & 6.60 & 46.78 & 21.27 & 20.53 & 14.47 & $\$$ \\
\hline \multicolumn{2}{|c|}{ Microcystin YR } & -- & 27.26 & 9.77 & -- & -- & $\$$ \\
\hline \multicolumn{2}{|c|}{ Microcystin LY } & -- & -- & -- & -- & -- & $\$$ \\
\hline
\end{tabular}

*dry riverbed; **moderate flows; ***High floods; -- Not detected in the water samples; WT water tap; \$ The water sample was lost during transit to the University of Johannesburg

The salinity results show that the salinity for each water taps 1 and tap 2 during the study period were high. The high salinity may promote the growth of cyanobacteria [23]. The levels of electrical conductivity (EC) and total dissolved solids (TDS) were found to be quite high with the range of 71.5 to 96.7 $\mu \mathrm{S} / \mathrm{cm}$ and 476 to $587 \mathrm{mg} / \mathrm{l} \mathrm{respectfully.} \mathrm{The} \mathrm{high} \mathrm{EC} \mathrm{and} \mathrm{TDS}$ level may promote the growth of cyanobacteria [24]. A high nitrate level, ranging from 0.5 to $0.8 \mathrm{mg} / \mathrm{L}$, this may provide nutritional food for cyanobacteria and promote their growth [25]. It was found that the phosphates were zero and this may imply that the phosphate is a limiting nutrient. Thus, only nitrogen fixing cyanobacteria may be available [26]. 
The results of dissolved organic carbon (surrogate for natural organic matter) showed that there were variations within the water taps and between the months and Limpopo River flows (Table 2). The significance of the absorbances results is as follows:

- $214 \mathrm{~nm}$ indicate the presence of nitrates and nitrites in water [27].

- $254 \mathrm{~nm}$ indicative of humic substances and aromatics [27].

- $272 \mathrm{~nm}$ the best predictor for Trihalomethane (THM) formation [27].

- $300 \mathrm{~nm}$ used by Rand Water and other treatment plants as a measure of DOC [27].

Thus at $214 \mathrm{~nm}$ wavelength for each water taps there were significant amount of (nutrients) nitrates and nitrites, and these nutrients may contribute to cyanobacteria growth in the raw water [25]. At $254 \mathrm{~nm}$ wavelength NOM absorbance was detected, this wavelength indicates that there are humic substances in water and may contribute to carbon sources for cyanobacteria growth. At 272 wavelengths NOM absorbance was high for each water tap 1 and tap 2 and this indicate that there is potential for trihalomethane formation when the raw water is chlorinated. At $300 \mathrm{~nm}$ wavelength DOC was also high, this implies that high amount of DOC in water contribute to cyanobacterial biofilm formation [16].

The SUVA result of $<2$ litre/(mg.M) indicates that the water samples were mainly composed of non-humic substances while, a SUVA result of $>4$ litre/(mg.M) may indicate that the water sample was mainly composed of humic substances [28]. The raw water samples of Musina are mainly composed of humic substances based on the information (Table 3).The SUVA results ranges from 2.08 to 6.30 and this indicate that there were ample carbon sources (humic substances) in the raw water to contribute to the growth of cyanobacteria. This was further collaborated by the DOC levels which were in the range of 2.31 to $7.27 \mathrm{ppm}$. The humic substances may promote the growth of cyanobacteria species in the raw water supply [29]. The corresponding high levels of DOC in the raw water may imply a higher growth of cyanobacteria since there will be ample carbon sources. This may be shown by the high levels of SUVA in water tap 1 as compared to water tap 2 , which influences the growth of cyanobacteria [30].

\section{B. The presence of microcystins in the raw water supply}

The water samples were assessed for the levels of different microcystin variants such as microcystin RR, microcystin LR, microcystin YR and microcystin LY (Table 2). The microcystins LR was the dominate microcystin congener [13]. These microcystins have been reported to affect human health and some of the symptoms may include weakness and anorexia [31]. The guideline value of $1.0 \mu \mathrm{g} / \mathrm{L}$ for microcystin LR for water intended for human consumption [32]. The microcystin LR levels that were found in Musina raw water supply were considerable higher than the WHO guideline value [32]. The occurrence of the microcystins LR and LY based on statistical mean was not significance different across the water taps 1 and $2(\mathrm{P}=0.24)$; marginal insignificance across the months $(\mathrm{P}=0.06)$ and highly significant across the microcystin congeners $(\mathrm{P}=0.03)$. This implies that the occurrence of the microcystins was dominated by the potent microcystin LR and the presence of microcystins throughout the months is worrisome event since these are toxins are harmful to humans on long term consumption of drinking water. The microcystin congeners, YR (which contains the Tyrosine and Arginine amino acids) and LY (which contains Leucine and Tyrosine amino acids) are currently not regulated by WHO and these microcystins are still considered as toxic and hazardous to humans ${ }^{23}$.

\section{The effects of physico-chemical parameters on cyanobacteria communities in the sediment samples}

The results shown in Fig.3 indicated that sediments were mainly composed of sand and minimal contribution of silt and clay. The study of Miller et al. [33] indicated that the loss of cyanotoxin, in the presence of soil particles, was due to adsorption processes onto the soil.
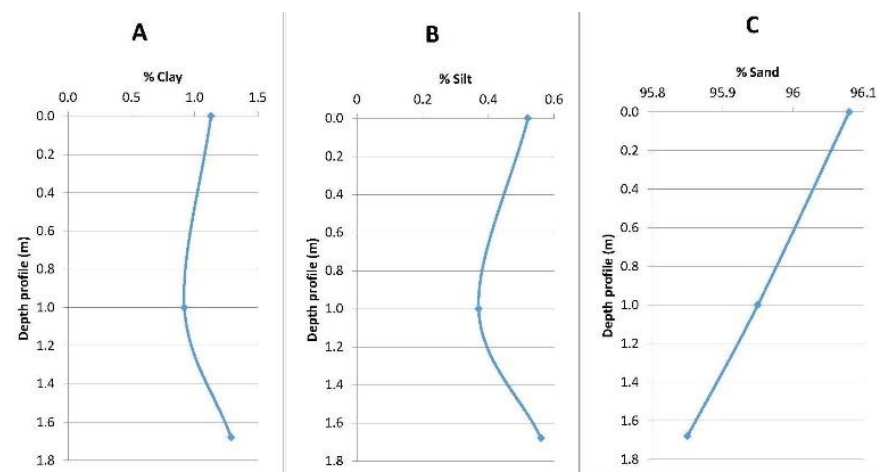

Fig 3: Percentage distribution of particles within the river sediment vertical profile

Several studies have demonstrated that high content of clay and silt are the important factor for adsorption of microcystins onto the sediments [12-13,33]. For this study, sediments from Limpopo River had low content of clay and silt and thus making the absence of the clay and silt leading to possible low level of adsorption of microcystins. Thus, riverbank filtration cannot be used as the candidate technique for the removal of microcystins in Limpopo River and this could explain the presence of microcystins in the raw water (Table 2).

The occurrence of cyanobacteria was also influenced by the availability nutrients in sediments. These nutrients would become available once the Limpopo River flowed again. The nutrients, phosphate and nitrate are the main nutrients that encourage the growth of cyanobacteria and were found (Figure 4). Although the water samples showed absence of soluble phosphates (Table 2), the sediment study indicated the richness of the sediments with the phosphates. The interesting observation was that the total nitrates increased downwards the river sediment profile (Fig 4B) and phosphates concentrations decreased with increasing depth (Fig 4A, C). Could perhaps explain the absence of phosphates in the borehole waters (Table 2)? 

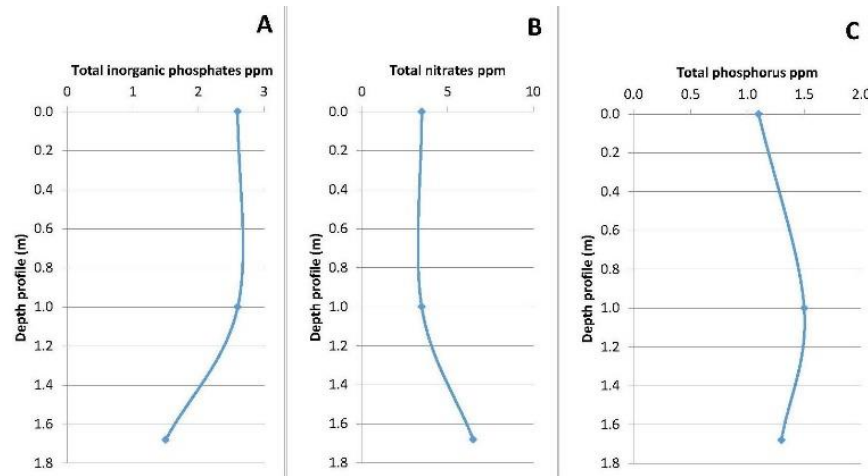

Fig 4. The distribution of total phosphorus (TP), total inorganic phosphorus (TIP) and total nitrate in the Limpopo river sediment profile.

The study showed that the level of total nitrate in sediments ranges from 3.5 to $6.2 \mathrm{mg} / \mathrm{l}$ (Figure 4). The highest content of total nitrate was measured in sediment sample 3 and was found to be $6.2 \mathrm{mg} / \mathrm{l}$. The high content found for total nitrogen in the sediments; probably indicated that cyanobacteria accumulate nitrogen by taking it from the sediment and from water as well. Nitrogen is usually the limiting for factor for cyanobacteria growth [34], a relative accumulation in phosphorus also occurs, although to a smaller degree compared with nitrogen.

\section{The composition of cyanobacteria communities in the samples}

The water and sediment samples were also incubated at room temperature under continuous lighting to stimulate the growth of cyanobacteria. After incubation for 30 days, the glass containers showed a green colouring and were identified as Microcystis and Planktothrix species (Fig 5). This may imply that the cyanobacteria species were present in the river sediment. Thus, by providing favourable conditions for these resting stages of the cyanobacteria were able to spring to life. The study of Chen et al. [4] also confirmed that Microcystis aeruginosa cells were viable in the lake sediment. Then moving down the sediment profile to $1.68 \mathrm{~m}$, the cyanobacteria species were also found and identified. These cyanobacteria species have been implicated in the production of microcystins (Table 2) [31] and may impact negatively on human health [32] and has been confirmed by this study. An interesting observation was the presence of diatoms in sediment profiles.

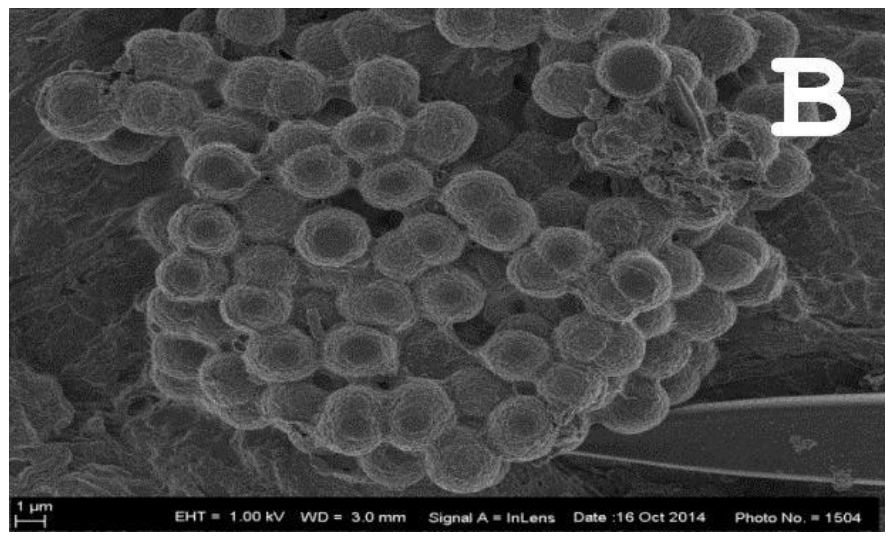

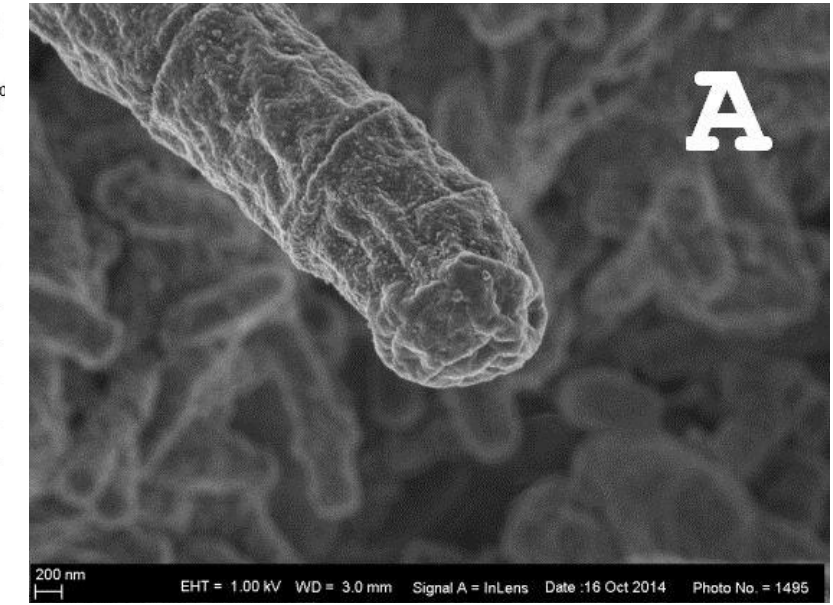

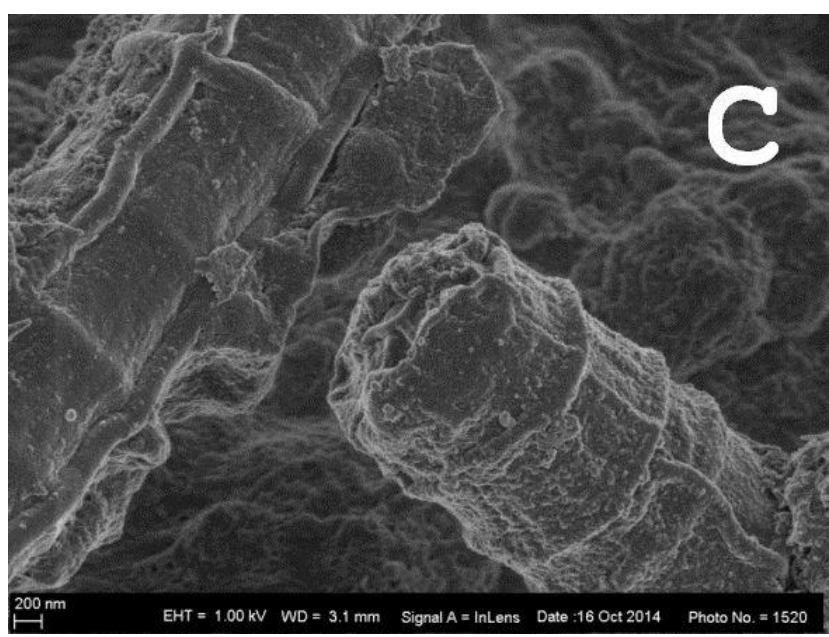

Fig. 5. The presence of (a) Planktothrix spp (surface Om), (b)Microcystis aeruginosa, Planktothrix spp (at a depth of $1.0 \mathrm{~m}$ ) and (d) Planktothrix spp (at a depth of 1.68m).

\section{CONCLUSION}

The study showed the presence of cyanobacteria species and their cyanotoxins $n$ the raw water supply. The environmental factors such as $\mathrm{pH}$, salinity, nutrients, dissolved organic carbon in the borehole water and sediments promote the proliferation of cyanobacteria. Further studies are required to determine the dissolved organic carbon, nutrients, diatoms, cyanobacteria and cyanotoxins in the sediment profile at greater depths of $30 \mathrm{~m}$ or more. The cyanotoxins showed the dominance of microcystin LR and likely impact on human health.

\section{ACKNOWLEDGMENT}

Eskom through their Tertiary Education Support Program (TESP) for funding (E320) the research study. The FlowCAM was purchased with funding from the Department of Science \& Technology and National Research Fund (UID 74406) and the University of Venda. Prof I Ncube (University of Limpopo) and Prof TM Msagati and Dr H Nyoni (University of Johannesburg) assisted with DOC and TOC analysis

\section{REFERENCES}

[1] Fosso-Kankeu E, Jagals P, Du Preez H. Exposure of rural households to toxic cyanobacteria in container-stored water. Water SA. 2008;34(5):631-6. 
https://doi.org/10.4314/wsa.v34i5.180660

[2] Magonono M, Oberholster PJ, Shonhai A, Makumire S, Gumbo JR. The presence of toxic and non-toxic cyanobacteria in the sediments of the Limpopo River Basin: Implications for human health. Toxins. 2018 $\mathrm{Jul} ; 10(7): 269$ https://doi.org/10.3390/toxins10070269

[3] Makhera, M., Gumbo, J.R., Chigayo, K., Monitoring of microcystin-LR in Luvuvhu River catchment: Implications for human health. African Journal of Biotechnology. 2011, 17;10(3):405-12.

[4] Chen, X., Xiang, H., Hu, Y., Zhang, Y., Ouyang, L., Gao, M., Fates of Microcystis aeruginosa Cells and Associated Microcystins in Sediment and the Effect of Coagulation Process on Them. Toxins. 2014; 6(1):152-167 https://doi.org/10.3390/toxins6010152

[5] Matilainen A, Gjessing ET, Lahtinen T, Hed L, Bhatnagar A, Sillanpää M. An overview of the methods used in the characterisation of natural organic matter (NOM) in relation to drinking water treatment. Chemosphere. 2011 Jun 1;83(11):1431-42. https://doi.org/10.1016/j.chemosphere.2011.01.018

[6] McKnight, D.M., Spectrofluorometric characterization of dissolved organic matter for indication of precursor organic material and aromaticity. Limnol.Oceanogr., 1991, 46(1), 38-48. https://doi.org/10.4319/lo.2001.46.1.0038

[7] World Health Organization (WHO). (2003). Guidelines for safe recreational water environments. Volume 1 , Coastal and fresh waters. Algae and cyanobacteria in fresh water.

[8] Latour D, Salençon MJ, Reyss JL, Giraudet H. Sedimentary imprint of Microcystis aeruginosa (Cyanobacteria) blooms in Grangent reservoir (Loire, France). Journal of Phycology. 2007 Jun;43(3):417-25 https://doi.org/10.1111/j.1529-8817.2007.00343.x

[9] Ihle T, Jähnichen S, Benndorf J. Wax and wane of Microcystis (Cyanophyceae) and microcystins in lake sediments: a case study in Quitzdorf reservoir (Germany). Journal of phycology. 2005 Jun;41(3):479-88. https://doi.org/10.1111/j.1529-8817.2005.00071.x

[10] Morris RJ, Williams DE, Luu HA, Holmes CF, Andersen RJ, Calvert SE. The adsorption of microcystin-LR by natural clay particles. Toxicon. 2000 Feb 1;38(2):303-8. https://doi.org/10.1016/S0041-0101(99)00149-X

[11] Harada KI, Imanishi S, Kato H, Mizuno M, Ito E, Tsuji K. Isolation of Adda from microcystin-LR by microbial degradation. Toxicon. $2004 \mathrm{Jul}$ 1;44(1):107-9. https://doi.org/10.1016/j.toxicon.2004.04.003

[12] Li J, Li J, Shi G, Mei Z, Wang R, Li D. Discerning biodegradation and adsorption of microcystin-LR in a shallow semi-enclosed bay and bacterial community shifts in response to associated process. Ecotoxicology and Environmental Safety. 2016 Oct 1;132:123-31. https://doi.org/10.1016/j.ecoenv.2016.05.033

[13] Xue Q, Steinman AD, Xie L, Yao L, Su X, Cao Q, Zhao Y, Cai Y. Seasonal variation and potential risk assessment of microcystins in the sediments of Lake Taihu, China. Environmental Pollution. 2020 Apr 1;259:113884 https://doi.org/10.1016/j.envpol.2019.113884

[14] Munusamy T, Hu YL, Lee JF. Adsorption and photodegradation of microcystin-LR onto sediments collected from reservoirs and rivers in Taiwan: a laboratory study to investigate the fate, transfer, and degradation of microcystin-LR. Environmental Science and Pollution Research. 2012 Jul 1;19(6):2390-9. https://doi.org/10.1007/s11356-012-0751-1

[15] Pereira LS, Pedrotti MF, Enders MS, Albers CN, Pereira JS, Flores EM. Multitechnique determination of halogens in soil after selective volatilization using microwave-induced combustion. Analytical chemistry. 2017 Jan 3;89(1):980-7. https://doi.org/10.1021/acs.analchem.6b04300

[16] Nkambule, T.I., Krause, R.W., Mamba, B.B., and Haarhoff, J., Removal of natural organic matter from water using ion-exchange resins and cyclodextrin polyurethanes. Physics and Chemistry of the Earth, 2009, 34(13-16): 812-818 https://doi.org/10.1016/j.pce.2009.07.013

[17] APHA, AWWA, WPCF. (1998). Standard Methods for the Examination of Water and Wastewater, 20th ed. Am. Pub. Health. Assoc., Washington D.C.

[18] Andersen JM. An ignition method for determination of total phosphorus in lake sediments. Water research. 1976 Jan 1;10(4):329-31. https://doi.org/10.1016/0043-1354(76)90175-5
[19] Strickland JD, Parsons TR. A Practical Handbook of Sea Water Analysis: Fisheries Research Board of Canada, Bull. No. 167.

[20] Abu Hilal AH, Abu Alhaija MM. Nutrients in water and sediments of King Talal Dam-Jordan. Jordan Journal of Biological Sciences. 2010 Jun;147(615):1-4.

[21] Krüger GH, Eloff JN. The influence of light intensity on the growth of different Microcystis isolates. Journal of the Limnological Society of southern Africa. 1977 Jan 1;3(1):21-5. https://doi.org/10.1080/03779688.1977.9632927

[22] Gumbo JR, Cloete TE. Light and electron microscope assessment of the lytic activity of Bacillus on Microcystis aeruginosa. African Journal of Biotechnology. 2011;10(41):8054-63. https://doi.org/10.5897/AJB10.1311

[23] Sekar, S., and Subramanian, G., Influence of low levels of salinity on the primary metabolism of the fresh water cyanobacteria Phormidium and Nostoc. Revista Brasileira de Fisiologia Vegetal, 1999, 11(2):83-89

[24] Masters GM, Ela WP. Introduction to environmental engineering and science. Englewood Cliffs, NJ: Prentice Hall; 2008.

[25] Kuffner, I.B., Paul, V.J., Effects of nitrate, phosphate and iron on the growth of macroalgae and benthic cyanobacteria from Cocos Lagoon, Guam. Marine Ecology Progress Series. 2001, 222:63-72 https://doi.org/10.3354/meps222063

[26] Larned, S.T., Nitrogen-versus phosphorus-limited growth and sources of nutrients for coral reef macroalgae. Marine Biology. 1998, 132(3):409-21 https://doi.org/10.1007/s002270050407

[27] Tshindane P, Mamba PP, Moss L, Swana UU, Moyo W, Motsa MM, Chaukura N, Mamba BB, Nkambule TT. The occurrence of natural organic matter in South African water treatment plants. Journal of Water Process Engineering. 2019 Oct 1;31:100809. https://doi.org/10.1016/j.jwpe.2019.100809

[28] Kiwa, N.V., Selection of anionic resins for NOM removal. In Proc. 2011 IWA Specialty Conference on Natural Organic Matter. Costa Mesa, CA, USA, July 2006 (pp. 27-29).

[29] Gjessing, E.T., Effect of aquatic humus on the biological availability of cadmium. Archiv fur hydrobiologie. 1981, 91: 144-149.

[30] Loffredo, E., D’Orazio, V., Brunetti, G., and Senesi, N., Adsorption of chlordane onto humic acids from pig slurry, Organic Geochemistry, 1999, 30, 443-451 https://doi.org/10.1016/S0146-6380(99)00029-7

[31] Codd, G.A., Morrison, L.F., and Metcalf, J.S., Cyanobacterial toxins: risk management for health protection. Toxicology and Applied Pharmacology, 2005, 203(3), 264-272 https://doi.org/10.1016/j.taap.2004.02.016

[32] World Health Organization (WHO). Toxic cyanobacteria in water, Chorus I, Bartram J, (Eds), E and FN Spoon, Routledge, London, 1999.

[33] Miller MJ, Critchley MM, Hutson J, Fallowfield HJ. The adsorption of cyanobacterial hepatotoxins from water onto soil during batch experiments. Water research. 2001 Apr 1;35(6):1461-8. https://doi.org/10.1016/S0043-1354(00)00419-X

[34] Wu Y, Li L, Zheng L, Dai G, Ma H, Shan K, Wu H, Zhou Q, Song L. Patterns of succession between bloom-forming cyanobacteria Aphanizomenon flos-aquae and Microcystis and related environmental factors in large, shallow Dianchi Lake, China. Hydrobiologia. 2016 Feb $1 ; 765(1): 1-3$ https://doi.org/10.1007/s10750-015-2392-0

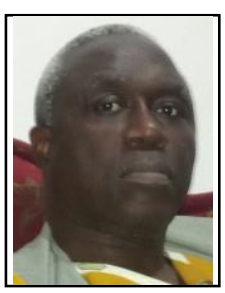

Prof Jabulani Ray Gumbo graduated with a $\mathrm{PhD}$ in Water Resources Management from University of Pretoria in 2007 and is a Associate Professor with University of Venda. He is member (M) of International Society for the Study of Harmful Algae; International Mine Water Association; Water Institute of Southern Africa; Microscopy Society of Southern Africa and South African Council for Natural Scientific Professions. He is the first or second author of more than 86 research outputs $(3$ patents, 38 peer reviewed papers with more than thirds of these published in international journals with an impact factor; 41 peer reviewed conference proceedings and 3 technical reports and four book chapters). He acts as a reviewer for NRF, national \& international journals, scientific member. 


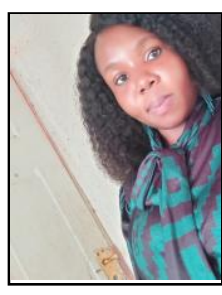

Ms Netshambidi Londani Konanani. Graduated with Bachelor of Earth Science in Hydrology and Water Resources from University of Venda in 2014. She is registered candidate scientist with SACNASP. Worked for the Department of Public Works as a Water Care candidate from 2015 to 2019, ensuring that drinking water that the municipality is supplying to the community complies with drinking water standard. She is working as a teacher for the Department of Education. 